\title{
Paleomagnetism of the Ishikoshi Andesite: a Middle Miocene paleomagnetic pole for northeastern Japan and tectonic implications
}

\author{
Hiroyuki Hoshi and Yuki Teranishi* \\ Department of Earth Sciences, Aichi University of Education, Kariya, Aichi 448-8542, Japan \\ (Received September 12, 2006; Revised March 6, 2007; Accepted March 7, 2007; Online published July 20, 2007)
}

\begin{abstract}
To determine a Middle Miocene paleomagnetic pole for northeastern Japan and discuss its tectonic implications, we obtained new paleomagnetic results from Middle Miocene (about $14 \mathrm{Ma}$ ) dacite and andesite flows of the Ishikoshi Andesite. Characteristic remanent magnetizations were isolated from 12 lava sites by means of detailed alternating field and thermal demagnetizations. Analysis of demagnetization results and rock magnetic experiments indicated that magnetite or Ti-poor titanomagnetite is the main magnetic carrier. We obtained a formation mean direction $\left(D=9.2^{\circ}, I=65.9^{\circ}, \alpha_{95}=7.3^{\circ}, k=40.5, N=11\right)$ and compared it with published paleomagnetic results from other areas of northeastern Japan to discuss tectonic rotation. This comparison provided a mean paleomagnetic pole $\left(85.9^{\circ} \mathrm{N}, 236.6^{\circ} \mathrm{E}, A_{95}=6.2^{\circ}, K=115.9, N=6\right)$ that we consider represents the Middle Miocene pole for northeastern Japan. It is statistically indistinguishable from coeval poles for southwestern Japan, South Korea, and northern China, and we therefore conclude that northeastern Japan as a whole has not been subjected to tectonic rotation since the Middle Miocene. A reassessment of geologic and paleomagnetic data suggests that a previous model of the Late Miocene or later counterclockwise rotation of northeastern Japan is based on tilt-uncorrected paleomagnetic directions from tilted rock units.
\end{abstract}

Key words: Paleomagnetism, rock magnetism, Ishikoshi Andesite, Middle Miocene, tectonics, northeastern Japan.

\section{Introduction}

Paleomagnetic studies have contributed significantly to the establishment of a broad consensus that northeastern and southwestern Japan rotated counterclockwise and clockwise, respectively, in the Early to Middle Miocene to form the present arcuate shape of the Japan arc (Otofuji et al., 1985a) (Fig. 1(a)). This dramatic event is believed to be causally related to the opening of Japan Sea back-arc basins (Otofuji et al., 1985a; Tamaki et al., 1992; Jolivet et al., 1995). During this back-arc opening stage, rapid crustal subsidence resulted in rapid sedimentation of terrigenous clastics and volcanic materials at the Japan Sea margins, presumably caused by an isostatic response to the extensional thinning of the continental crust and/or to the thermal attenuation of it (Yamaji, 1990; Sato and Amano, 1991). In Japan, late Neogene and Quaternary crustal deformation has partly been influenced by structural elements that formed in the Japan Sea opening stage (e.g., Okamura et al., 1995; Van der Werff, 2000). Detailed exploration of the Miocene rotation of northeastern and southwestern Japan is, therefore, crucial not only for illustrating the geotectonic history of circum-Japan Sea regions of eastern Asia but also for studying active tectonic processes.

\footnotetext{
* Now at Hagiwara Elementary School, Ichinomiya, Aichi 491-0353, Japan.

Copyright (c) The Society of Geomagnetism and Earth, Planetary and Space Sciences (SGEPSS); The Seismological Society of Japan; The Volcanological Society of Japan; The Geodetic Society of Japan; The Japanese Society for Planetary Sciences; TERRAPUB.
}

This study focuses on the Middle Miocene tectonics of northeastern Japan. The timing of the counterclockwise rotation has long been the subject of debate. Otofuji et al. $(1985 \mathrm{~b}, 1994)$ proposed a simple kinematic model involving the fan-shaped opening of the Japan Sea, in which northeastern Japan rotated simultaneously with the clockwise rotation of southwestern Japan at about $15 \mathrm{Ma}$ (Middle Miocene). In contrast to this interpretation, some paleomagnetic measurements suggest that the rotation of northeastern Japan was a few million years earlier than that of southwestern Japan (Yamazaki, 1989; Tanaka et al., 1991; Hoshi and Takahashi, 1997; Hoshi and Matsubara, 1998; Takahashi et al., 1999). A review of paleomagnetic data (Hoshi and Takahashi, 1999) led to the conclusion that the rotation of northeastern Japan was in the Early Miocene (approx. 21-18 Ma). However, other researchers have documented northwesterly directions from younger, Middle Miocene (approx. 15-14 Ma) rocks. For example, Hirooka et al. (1990) and Momose et al. (1990) reported northwesterly directions from sediments in the back-arc region that were dated biostratigraphically at 15-14 Ma. Such directions are considered to represent intra-arc block rotation during or after the formation of the Japan Sea (Oda et al., 1989; Hirooka et al., 1990; Hoshi and Matsubara, 1998; Yamaji et al., 1999; Mino et al., 2001). Yamaji et al. (1999) argued that the block rotation was associated with transtensional deformation.

In an attempt to obtain more data on the rotation of northeastern Japan and intra-arc deformation, we collected samples from the Middle Miocene Ishikoshi Andesite, which is 
(a)

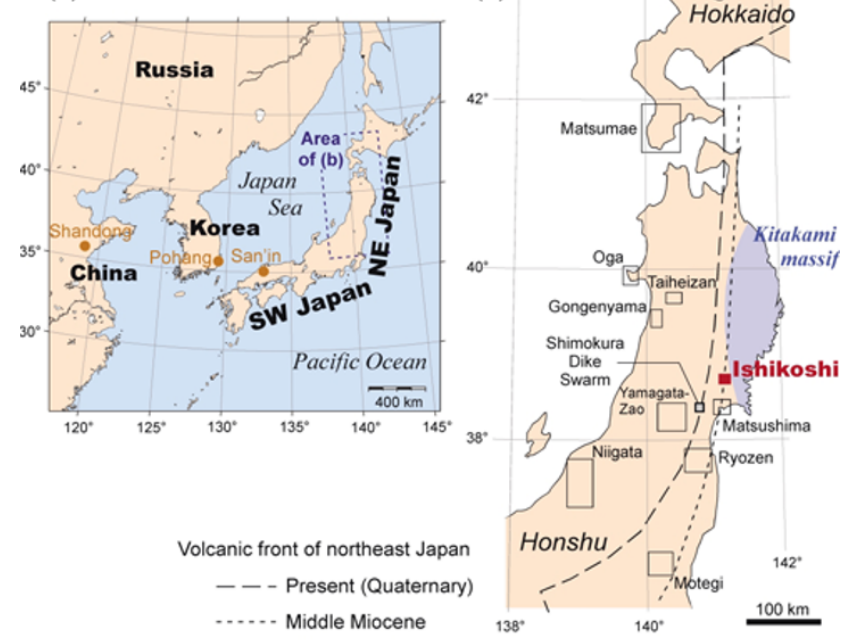

Fig. 1. (a) Map of the Japan arc (northeastern Japan and southwestern Japan) and the eastern margin of the Asian continent. (b) Map of northeastern Japan showing the locations of the Ishikoshi area (this study), Shimokura Dike Swarm (Tsunakawa et al., 1985), and areas from which Middle Miocene paleomagnetic data have been reported. The ancient and present volcanic fronts are indicated by short and long dashed lines, respectively.

exposed at the southwestern margin of the Kitakami massif (Fig. 1(b)). Based on compilation of reliable paleomagnetic data, including our newly obtained direction, we have determined a Middle Miocene paleomagnetic pole for northeastern Japan. This pole is compared with coeval ones for other circum-Japan Sea regions (southwestern Japan, South Korea, and northern China) in terms of the tectonics.

We also focus on a tectonic model where northeastern Japan experienced a second, small (approx. 20 ${ }^{\circ}$ ) counterclockwise rotation in the Late Miocene or later (Tsunakawa et al., 1985). This model is based on a paleomagnetic direction from nested parallel dikes, collectively called the Shimokura Dike Swarm, which is situated approximately $60 \mathrm{~km}$ southwest of the Ishikoshi Andesite (Fig. 1). Near the Shimokura Dike Swarm, northerly formation mean directions that are inconsistent with the model have previously been documented from sediments of the Matsushima area (Yamazaki, 1989) and volcanic rocks of the Yamagata area (Hoshi et al., 1992, 1998), both of which are of Middle Miocene age. Using paleomagnetic data, including the Ishikoshi direction described herein and available geological information, we report our testing of this rotation model.

\section{Geology, Sampling, and Laboratory Proce- dures}

The Ishikoshi Andesite crops out in a hilly area on the southwestern margin of the Kitakami massif (Fig. 1(b)). This volcanic formation lies on the early Middle Miocene (16-14 Ma) volcanic front, which was shifted eastward by several tens of kilometers from the present position (Hoshi and Takahashi, 1996) (Fig. 1(b)). The volcanic rocks on this ancient volcanic field are generally fresh, probably due to their relatively great distance from sites of later volcanism and hydrothermal activity and, therefore, are suitable for paleomagnetic study (Hoshi and Takahashi, 1996,

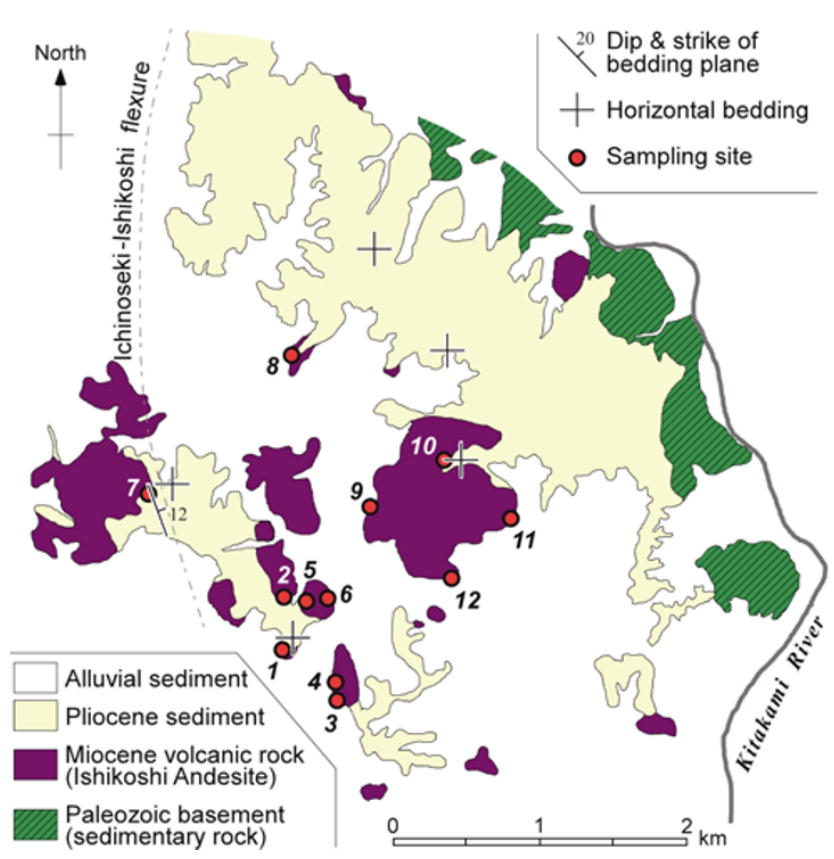

Fig. 2. Simplified geological map of the Ishikoshi area after Matsuno (1967) and Takeuchi and Kaneko (1996). Bedding attitudes were investigated by the present authors. The locations of paleomagnetic sampling sites are also indicated.

1997; Hoshi and Matsubara, 1998; Takahashi et al., 1999). The geology of the Ishikoshi area was described in a series of geological maps published by the Geological Survey of Japan (Matsuno, 1967; Takeuchi and Kaneko, 1996). The Ishikoshi Andesite consists of porphyritic lavas of dacite and andesite, with minor amounts of volcaniclastic deposits. Unaltered, columnar-jointed lavas are found at several active and inactive quarries. Toshida et al. (1999) reported a K-Ar age of 13.5 $\pm 0.2 \mathrm{Ma}$ (Middle Miocene). This formation is thought to rest unconformably on the Paleozoic to Mesozoic basement rocks that comprise the $\mathrm{Ki}$ takami massif, and is, in turn, covered unconformably by Pliocene and Quaternary sedimentary blankets (Matsuno, 1967; Takeuchi and Kaneko, 1996). In the field, we drilled 95 cores from 12 lava sites for paleomagnetic measurements (Fig. 2). The cores were oriented with a magnetic compass.

Detailed information on the structural attitude of the Ishikoshi Andesite is lacking, primarily because it consists predominantly of thick lavas, making it impossible to find stratification in the outcrop. However, there are some indirect lines of evidence suggesting insignificant or the absence of tilting, with the exception of localized deformation along a north-trending flexural structure (described below). At some quarries-for example, at sites 2, 3, 4, and 8 (Fig. 2)-we observed the development of vertical columnar joints in the central massive parts of thick lavas, suggesting little or no tilting since cooling. At some localities we also found that the Pliocene sediments covering the Ishikoshi Andesite have a horizontal bedding, as depicted in Fig. 2. In other Miocene sedimentary basins developed on the southwestern margin of the Kitakami massif, such as the Matsushima area (Fig. 1(b)), Middle Miocene and younger 


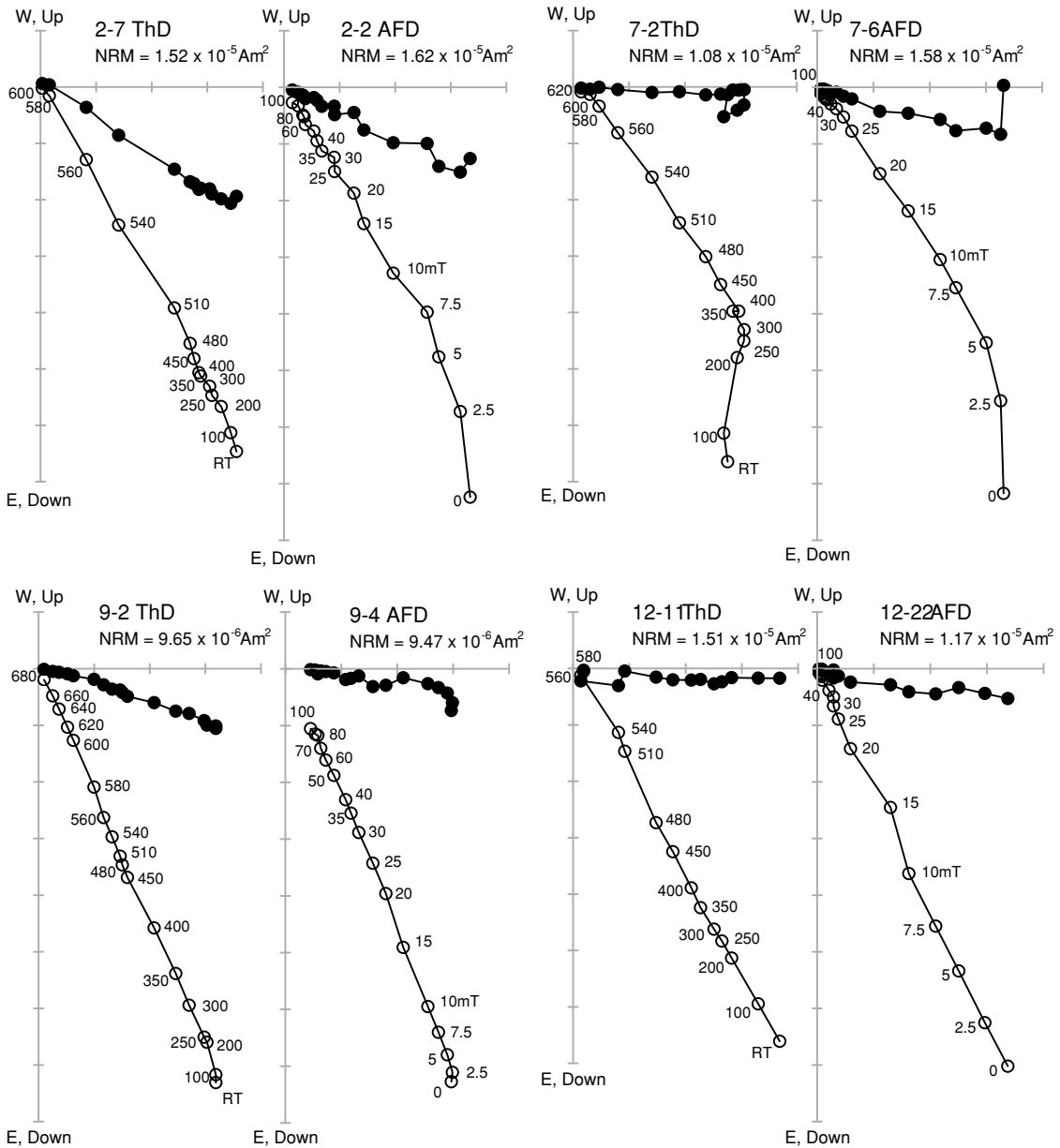

Fig. 3. Examples of orthogonal vector plots for representative samples. Solid circles are vector endpoints projected onto the horizontal plane, and open circles are those onto the $\mathrm{N}-\mathrm{S}$ vertical plane. AFD, alternating field demagnetization; ThD, thermal demagnetization.

strata generally show horizontal or subhorizontal bedding (Ishii et al., 1982, 1983), which would indicate rather weak upper crustal deformation. On the basis of these observations, we interpret that-with the exception of rocks along the flexure-the Ishikoshi Andesite has not suffered significant tilting; hence, paleomagnetic tilt correction is unnecessary.

An exceptionally deformed zone exists along the northtrending Ichinoseki-Ishikoshi Flexure (Fig. 2), and site 7 is situated near the inferred flexure axis (the location of the inferred axis is according to Matsuno, 1967). Matsuno (1967) reported that this flexural structure has been growing since the Pliocene and that the Pliocene sediments on and close to the axis exhibit eastward dips. We confirmed gentle (approximately $10^{\circ}$ ) dips at an outcrop located on or close to the inferred axis, some $200 \mathrm{~m}$ to the southeast of site 7 , but $300 \mathrm{~m}$ further to the northeast we found horizontal bedding planes. We infer from these observations that tilting at site 7 is insignificant, but it is hard to evaluate precisely the amount of tilt. Consequently, we do not include this site into the calculation on the formation mean direction.

In the laboratory, oriented core samples were cut into 22-mm-high cylindrical specimens for paleomagnetic/rock magnetic measurements which were carried out at Aichi University of Education. Remanent magnetization was measured using a spinner magnetometer (Natsuhara-Giken
ASPIN). The stability of the natural remanent magnetization (NRM) was examined by stepwise alternating filed and thermal demagnetizations (AFD and ThD). Stepwise AFD was carried out in more than 15 steps up to $100 \mathrm{mT}$, and stepwise ThD was done in air in more than 12 steps up to $680^{\circ} \mathrm{C}$. Remanent magnetization components were examined using orthogonal vector plots (Zijderveld, 1967) and principal component analysis (Kirschvink, 1980). Site mean remanent magnetization directions were calculated using Fisher (1953) statistics. To elucidate magnetic mineralogy, we subjected some specimens to rock magnetic experiments using isothermal remanent magnetization (IRM).

\section{Results}

At all 12 sites, characteristic remanent magnetization (ChRM) components with identical directions were isolated by both AFD and ThD techniques (Fig. 3). These ChRMs possess a northerly and down (normal polarity) direction. Small, unstable components were completely erased by $10 \mathrm{mT}$ or $300^{\circ} \mathrm{C}$. Site mean ChRM directions are listed in Table 1 and plotted in Fig. 4, and were calculated by combining specimen ChRM directions with a maximum angular deviation (MAD; Kirschvink, 1980) of less than $10^{\circ}$, as revealed by both demagnetization techniques. The site mean directions displayed a moderate angular dispersion, which is probably attributed to the adequate sampling of the ge- 
Table 1. Summary of paleomagnetic data obtained from the Ishikoshi Andesite (approx. 14 Ma, Middle Miocene), Miyagi Prefecture, northeastern Japan.

\begin{tabular}{|c|c|c|c|c|c|c|c|c|}
\hline \multirow[t]{2}{*}{ Site } & \multirow[b]{2}{*}{ (N lat, E long) } & \multirow[t]{2}{*}{$N$} & \multirow{2}{*}{$\begin{array}{c}D \\
\left(^{\circ}\right)\end{array}$} & \multirow{2}{*}{$\begin{array}{c}I \\
\left({ }^{\circ}\right)\end{array}$} & \multirow{2}{*}{$\begin{array}{c}\alpha_{95} \\
\left(^{\circ}\right)\end{array}$} & \multirow[t]{2}{*}{$k$} & \multicolumn{2}{|c|}{ VGP } \\
\hline & & & & & & & $\left({ }^{\circ} \mathrm{N}\right)$ & $\left({ }^{\circ} \mathrm{E}\right)$ \\
\hline 1 & $38^{\circ} 44^{\prime} 27.2^{\prime \prime}, 141^{\circ} 11^{\prime} 55.3^{\prime \prime}$ & 8 & 34.4 & 72.4 & 5.5 & 102.0 & 60.8 & 179.6 \\
\hline 2 & $38^{\circ} 44^{\prime} 49.2^{\prime \prime}, 141^{\circ} 11^{\prime} 56.9^{\prime \prime}$ & 8 & 27.7 & 58.8 & 3.9 & 201.1 & 68.6 & 220.3 \\
\hline 3 & $38^{\circ} 44^{\prime} 00.3^{\prime \prime}, 141^{\circ} 12^{\prime} 24.4^{\prime \prime}$ & 7 & 63.6 & 86.3 & 8.8 & 47.6 & 41.7 & 150.1 \\
\hline 4 & $38^{\circ} 44^{\prime} 13.0^{\prime \prime}, 141^{\circ} 12^{\prime} 25.6^{\prime \prime}$ & 7 & 7.4 & 77.7 & 12.2 & 25.4 & 62.0 & 147.5 \\
\hline 5 & $38^{\circ} 44^{\prime} 48.2^{\prime \prime}, 141^{\circ} 12^{\prime} 08.2^{\prime \prime}$ & 8 & 4.6 & 67.0 & 1.7 & 1081.2 & 78.6 & 156.4 \\
\hline 6 & $38^{\circ} 44^{\prime} 48.1^{\prime \prime}, 141^{\circ} 12^{\prime} 20.5^{\prime \prime}$ & 8 & 2.7 & 62.7 & 2.5 & 487.0 & 84.3 & 161.1 \\
\hline $7^{*}$ & $38^{\circ} 45^{\prime} 35.3^{\prime \prime}, 141^{\circ} 10^{\prime} 38.3^{\prime \prime}$ & 8 & 6.5 & 55.2 & 3.4 & 272.2 & 84.0 & 259.5 \\
\hline 8 & $38^{\circ} 46^{\prime} 33.9^{\prime \prime}, 141^{\circ} 11^{\prime} 59.8^{\prime \prime}$ & 8 & 1.8 & 48.5 & 3.3 & 279.9 & 80.6 & 311.6 \\
\hline 9 & $38^{\circ} 45^{\prime} 30.4^{\prime \prime}, 141^{\circ} 12^{\prime} 42.2^{\prime \prime}$ & 8 & 12.5 & 64.7 & 2.4 & 550.2 & 77.9 & 186.6 \\
\hline 10 & $38^{\circ} 45^{\prime} 48.7^{\prime \prime}, 141^{\circ} 13^{\prime} 26.7^{\prime \prime}$ & 8 & 20.6 & 64.7 & 2.4 & 528.5 & 73.0 & 197.1 \\
\hline 11 & $38^{\circ} 45^{\prime} 24.3^{\prime \prime}, 141^{\circ} 14^{\prime} 06.3^{\prime \prime}$ & 6 & 340.5 & 53.2 & 5.4 & 155.3 & 73.5 & 39.6 \\
\hline 12 & $38^{\circ} 44^{\prime} 57.7^{\prime \prime}, 141^{\circ} 13^{\prime} 28.6^{\prime \prime}$ & 6 & 10.3 & 60.1 & 5.7 & 136.9 & 81.8 & 212.0 \\
\hline \multicolumn{2}{|c|}{ Mean direction** } & 11 & 9.2 & 65.9 & 7.3 & 40.5 & & \\
\hline \multicolumn{2}{|c|}{ Mean VGP (paleomagnetic pole) ${ }^{* *}$} & 11 & & & 10.7 & 19.0 & 76.8 & 171.0 \\
\hline
\end{tabular}

$N$, number of specimens used for site mean calculation; $D$, declination; $I$, inclination; $\alpha_{95}$, radius of $95 \%$ confidence circle about the direction; $k$, Fisher's (1953) precision parameter; VGP, virtual geomagnetic pole. ${ }^{*}$ Site 7 could have been affected by small tilting (see text). ${ }^{* *}$ Site 7 is excluded.

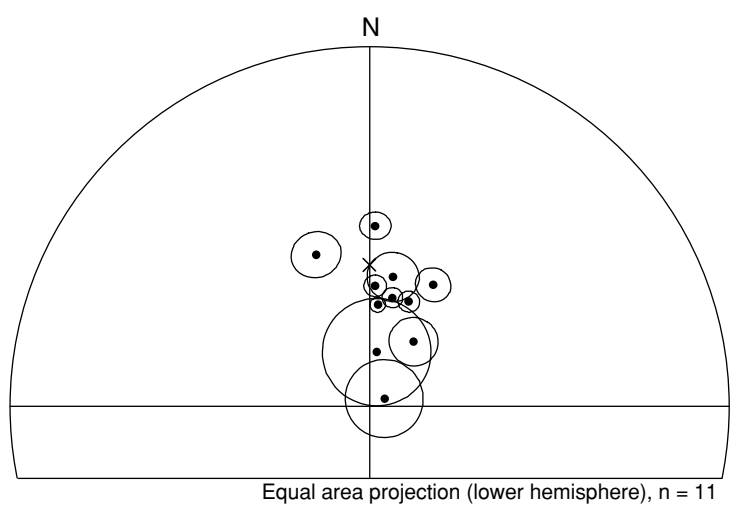

Fig. 4. Equal-area projection of site mean characteristic remanent magnetization directions with 95\% confidence ellipses for the Ishikoshi Andesite, obtained by this study (see Table 1 for data). The geocentric axial dipole field direction at Ishikoshi is shown by the cross $\left(D=0^{\circ}\right.$, $\left.I=57.9^{\circ}\right)$.

omagnetic paleosecular variation, as discussed later. Excluding site 7 where unrecognizable tilt is likely, 11 sites have a formation mean $D=9.2^{\circ}, I=65.9^{\circ}, \alpha_{95}=7.3^{\circ}$, $k=40.5$. The corresponding paleomagnetic pole, derived by averaging the virtual geomagnetic poles (VGPs) for 11 sites, falls at $76.8^{\circ} \mathrm{N}, 171.0^{\circ} \mathrm{E}\left(A_{95}=10.0^{\circ}, K=19.0\right)$.

The demagnetization results suggest that magnetite and Ti-poor titanomagnetite are the main carriers of NRMs at all sites. Stepwise ThD revealed unblocking temperature spectra in which the remanent magnetization intensities of most specimens were largely decreased above $480^{\circ} \mathrm{C}$ and reached to less than $2 \%$ of the original NRMs at $560-600^{\circ} \mathrm{C}$ (Fig. 3). Rock magnetic experiments using IRM support this. A stepwise acquisition experiment of IRM was performed on an AF-demagnetized specimen of site 2 with a pulse magnetizer and showed that the IRM intensity was saturated in applied magnetic fields of approximately $0.1 \mathrm{~T}$ (Fig. 5(a)), suggesting that the dominant magnetic minerals have relatively low coercivities. Stepwise ThD of composite IRM (Lowrie, 1990) was carried out on the same specimen, onto which we applied, prior to $\mathrm{ThD}$, direct magnetic fields of 3, 0.4, and $0.12 \mathrm{~T}$ in orthogonal directions to impart a composite IRM. The results shown in Fig. 5(b) reveal that we did find a dominant soft fraction with stepwise decay that shows two major drops around $300^{\circ} \mathrm{C}$ and $550^{\circ} \mathrm{C}$; the former would suggest titanomagnetite with intermediate $\mathrm{Ti}$ content, and the latter is a clear indication of Ti-poor titanomagnetite. On the basis of these results, we conclude that the site mean directions reside mainly in magnetite or Ti-poor titanomagnetite.

Site 9 is the sole case where hematite contributes slightly to the NRM. Significant portions of original NRM intensities survived after $\mathrm{ThD}$ up to $600^{\circ} \mathrm{C}$, and they decayed gradually during the course of the treatments at higher temperatures, finally vanishing at $680^{\circ} \mathrm{C}$ (Fig. 3). The presence of high-coercivity minerals such as hematite was inferred both from the AFD results and from the unsaturated curve observed in the progressive IRM acquisition up to $3 \mathrm{~T}$ (Fig. 5(a)). In the stepwise ThD test of composite IRM (Fig. 5(c)), the small but visible hard fraction was largely unblocked above $600^{\circ} \mathrm{C}$, and the medium and soft fractions also disappeared above $600^{\circ} \mathrm{C}$ following the major drop around $580^{\circ} \mathrm{C}$, revealing magnetite. The hematite is considered to be of secondary origin because the rock specimens of this site have been affected by minor alterations; mafic phenocryst minerals (mostly hornblende) have partly been replaced by brownish alteration products, probably hematite or Ti-poor ilmenohematite. Although the directional difference between the components carried by magnetite and those by hematite was small (e.g. specimen 9-2 in Fig. 3), we adopted the magnetite component seen below $580^{\circ} \mathrm{C}$ as the acceptable component of this site. 
(a)

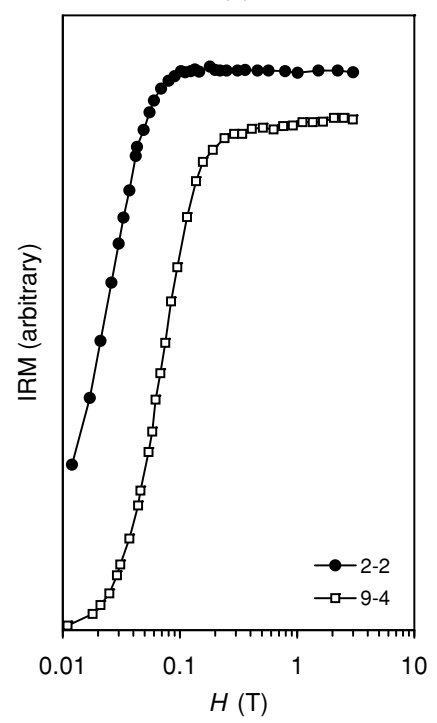

(b)

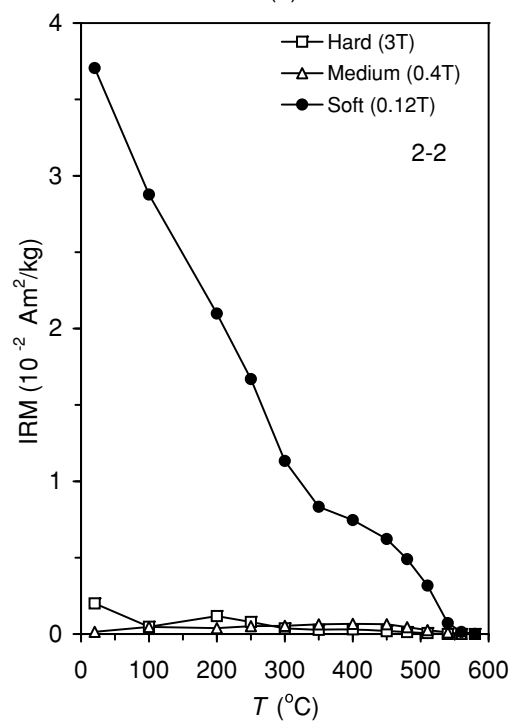

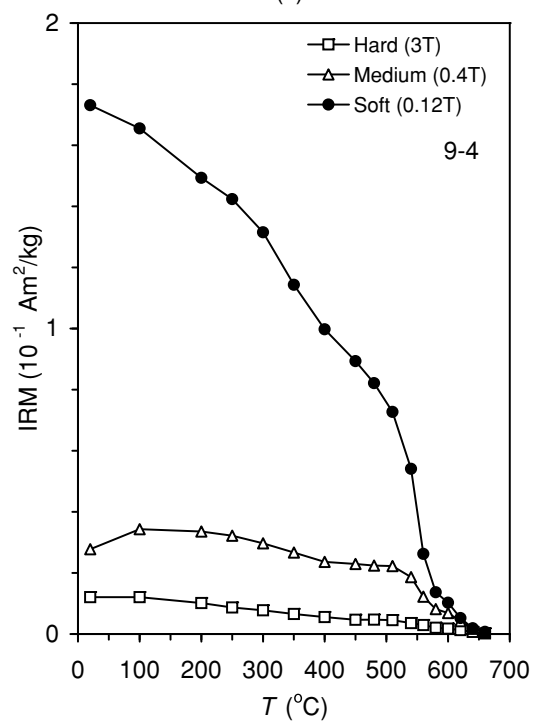

Fig. 5. Results of rock magnetic experiments. (a) Stepwise acquisition of isothermal remanent magnetization (IRM). (b, c) Stepwise thermal demagnetization of the composite IRM.

\section{Discussion}

\subsection{Reliability of the data}

Here we discuss the reliability of the northerly and down overall mean direction for the Ishikoshi Andesite because it is close to the geocentric axial dipole field direction $\left(D=0^{\circ}, I=57.9^{\circ}\right)$ and has only a normal polarity. Based on the following observations, the Ishikoshi direction is presumed to be a primary magnetization. (1) In stepwise demagnetization experiments, the low-temperature or lowcoercivity components were efficiently removed by $\mathrm{AF}$ and thermal methods, and specimen ChRM components with high unblocking temperatures or coercivities were rigorously isolated from NRMs, as typically shown in the orthogonal diagrams for site 7 specimens (Fig. 3). As a result, most site means have high $k$ values (precision or concentration parameter) of more than 100. (2) Stepwise demagnetization of NRMs and rock magnetic analysis for selected specimens showed that the ChRM components reside primarily in magnetite or Ti-poor titanomagnetite (Figs. 3, 5). In site 9 rocks, Ti-poor ilmenohematite or hematite was also suggested to be contained as an alteration product, but we employed only the magnetite component below $580^{\circ} \mathrm{C}$ in calculating a site mean direction. Ferromagnetic iron sulphides, such as pyrrhotite, which often occurs in rocks subjected to hydrothermal alteration, were not recognizable in the Ishikoshi Andesite. (3) Ishikoshi Andesite rocks in general appear to be fresh and unaltered, in contrast to the Miocene or older rocks on the back-arc side of northeastern Japan that have suffered extensive hydrothermal alteration (e.g. Shimazu, 1991). In the Ishikoshi area, there is no evidence of later volcanism, metamorphism, and/or hydrothermal alteration.

As noted above, a moderate dispersion of site mean directions is thought to reflect the sampling of the paleomagnetic secular variation. This can be tested by an analysis of the angular standard deviation (ASD) of the VGPs. Using the method of Cox (1969), the 11 VGPs (excluding site
7) give an ASD of $18.8^{\circ}$, with lower and upper $95 \%$ confidence limits $\left(S_{l}\right.$ and $\left.S_{u}\right)$ of $14.7^{\circ}$ and $26.1^{\circ}$, respectively. This result appears to be slightly larger than the $0-5 \mathrm{Ma}$ global trend $\left(15.74^{\circ}, S_{l}=15.08^{\circ}, S_{u}=16.46^{\circ}\right)$ calculated for the latitude range $35.0-39.9^{\circ}$ from a worldwide database (McElhinny and McFadden, 1997), and this deviation may be due to the potential errors derived from a small undetectable tilt of volcanic rocks. We emphasize, however, that the results do overlap within the margins of error, and it is thus more likely that the Ishikoshi overall mean direction is a time-averaged one in which the paleosecular variation is adequately averaged out. In summary, we conclude that the northerly and down direction of the Ishikoshi Andesite is reliable and suitable for use in discussions on tectonics.

\subsection{Middle Miocene paleomagnetic pole for northeast- ern Japan and tectonic implications}

The formation mean direction of the Ishikoshi Andesite has a northerly declination, thereby suggesting the absence of vertical-axis rotation. The inclination is somewhat steeper than that expected in the geocentric axial dipole field, and clearly the principal cause of this is the presence of a few steep site mean directions (sites 1, 3, and 4, Table 1). The steep site mean directions would be due to the paleosecular variation; therefore, to average out the paleosecular variation, we do not preclude such results from the calculations on a formation mean direction.

We compare the Ishikoshi direction with Middle Miocene (approx. 16-11 Ma) paleomagnetic results from other areas (Tosha and Hamano, 1988; Yamazaki, 1989; Hirooka et al., 1990; Fujiwara, 1992; Hoshi and Takahashi, 1997; Takahashi et al., 1999). Selected results are listed in Table 2, which originate from the entire length of northeastern Japan, including southwestern Hokkaido (Matsumae), northern Honshu (Oga, Ishikoshi, Matsushima, Ryozen), and central Honshu (Motegi, Niigata). In Table 2, reversed polarity directions have been standardized to a normal polarity. All the data are formation mean directions with a 
Table 2. Selected Middle Miocene paleomagnetic data of northeastern Japan. The formation means with the quality factor ( $Q$ : Van der Voo, 1990, $1993) \geq 3$ are listed.

\begin{tabular}{|c|c|c|c|c|c|c|c|c|c|c|c|}
\hline \multirow[t]{2}{*}{ Area (N/E, deg) } & \multirow{2}{*}{$\begin{array}{r}\text { Age } \\
(\mathrm{Ma})\end{array}$} & \multirow[t]{2}{*}{$n$} & \multicolumn{4}{|c|}{ Paleomagnetic pole } & \multirow{2}{*}{$\begin{array}{r}D \\
\left({ }^{\circ}\right) \\
\end{array}$} & \multirow{2}{*}{$\begin{array}{r}I \\
\left({ }^{\circ}\right) \\
\end{array}$} & \multirow{2}{*}{$\begin{array}{r}\alpha_{95} \\
\left({ }^{\circ}\right) \\
\end{array}$} & \multirow[t]{2}{*}{$k$} & \multirow[t]{2}{*}{ Ref. } \\
\hline & & & $\left({ }^{\circ} \mathrm{N}\right)$ & $\left({ }^{\circ} \mathrm{E}\right)$ & $A_{95}\left({ }^{\circ}\right)$ & $K$ & & & & & \\
\hline \multicolumn{12}{|l|}{ Northeastern Japan } \\
\hline Ishikoshi (38.8/141.2) & 14 & 11 & 76.8 & 171.0 & 10.7 & 19.0 & 9.2 & 65.9 & 7.3 & 40.5 & This study \\
\hline Matsumae (41.5/140.3) & $11-15$ & 6 & 82.1 & 252.2 & 15.6 & 19.4 & 9.1 & 55.1 & 12.9 & 27.8 & Fujiwara (1992) \\
\hline Oga (40.0/139.7) & 15 & 4 & 89.5 & 284.7 & 11.2 & 67.8 & 0.4 & 57.8 & 9.5 & 94.3 & Tosha and Hamano (1988) \\
\hline Niigata (37.5/139.1) & 15 & 4 & 67.9 & 31.8 & 6.2 & 218.0 & -23.9 & 47.8 & 7.1 & 169.0 & Hirooka et al. (1990) \\
\hline Matsushima (38.3/141.1) & $15-16$ & 6 & 79.5 & 296.6 & 9.3 & 52.6 & 5.0 & 48.1 & 12.2 & 31.2 & Yamazaki (1989) \\
\hline Ryozen (37.7/140.8) & 16 & 11 & 88.9 & 333.6 & 9.8 & 22.5 & -0.3 & 57.1 & 8.1 & 32.8 & Takahashi et al. (1999) \\
\hline Motegi (36.6/140.2) & 16 & 11 & 84.2 & 229.7 & 10.9 & 18.5 & 7.4 & 58.0 & 9.1 & 26.0 & Hoshi and Takahashi (1997) \\
\hline Mean* & & & 85.9 & 236.6 & 6.2 & 115.9 & ( 6 form & tion-m & ans) & & \\
\hline \multicolumn{12}{|l|}{ Southwestern Japan } \\
\hline San'in $(35 / 133)$ & 15 & 18 & 86.1 & 214.0 & 10.5 & & & & & & Otofuji et al. (1991) \\
\hline \multicolumn{12}{|l|}{ South Korea } \\
\hline Pohang (36.2/129.3) & $12-17$ & 22 & 84.9 & 292.6 & 4.0 & & & & & & Lee et al. (1999) \\
\hline \multicolumn{12}{|l|}{ Northern China } \\
\hline Shandong (36.2/118.5) & $14-18$ & 12 & 85.2 & 238.4 & 5.6 & & & & & & Zhao et al. (1994) \\
\hline
\end{tabular}

$n$, number of sites; $A_{95}$, radius of $95 \%$ confidence circle about the paleomagnetic pole; $D$ and $I$, formation mean declination and inclination expected at Ishikoshi; $\alpha_{95}$, radius of $95 \%$ confidence circle about the formation mean direction. $K$ and $k$, Fisher's (1953) precision parameter. ${ }^{*}$ Pole for Niigata is excluded from calculation.

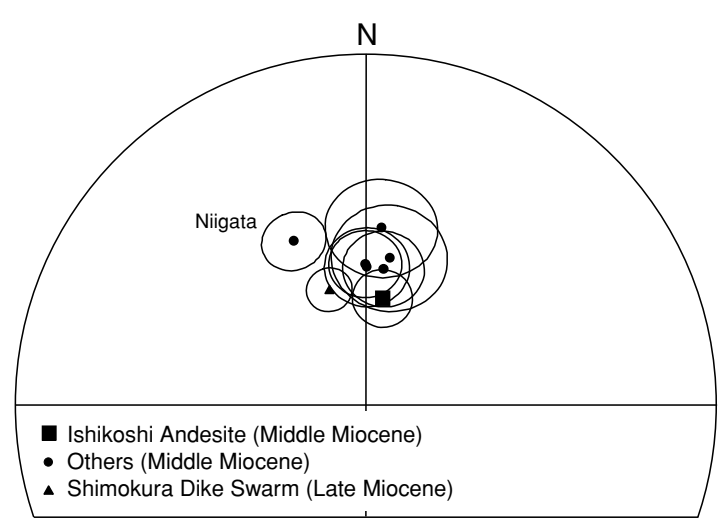

Equal area projection (lower hemisphere)

Fig. 6. Selected Middle Miocene formation mean directions of northeastern Japan (see Table 2 for data). Also plotted is the overall mean direction of the Late Miocene Shimokura Dike Swarm $\left(D=342.0^{\circ}\right.$, $I=62.1^{\circ}, \alpha_{95}=5.2^{\circ}$; Tsunakawa et al., 1985). All are standardized to a normal polarity. Ellipses show the $95 \%$ confidence intervals around the mean directions.

quality factor ( $Q$ : Van der Voo, 1990, 1993) of at least three. Each direction has age information determined from radiometric and/or biostratigraphic and/or magnetostratigraphic approaches and a presumption that the magnetization is the same age (No. 1 of Van der Voo's criteria); has a sufficient number of samples, and the $95 \%$ confidence limits $\left(\alpha_{95}\right.$, $\left.A_{95}\right)$ are not large $\left(\leq 16^{\circ}\right)$ (No. 2$)$; comes from ChRM components isolated by alternating field and/or thermal demagnetization (No. 3). The declination and inclination values shown in Table 2 are those expected at Ishikoshi, recalculated by the present authors based on paleomagnetic pole positions described in the literature.

With the exception of Niigata, all have a similar direction with a northerly declination (Fig. 6). This demonstrates the absence of relative rotation between the widely spaced

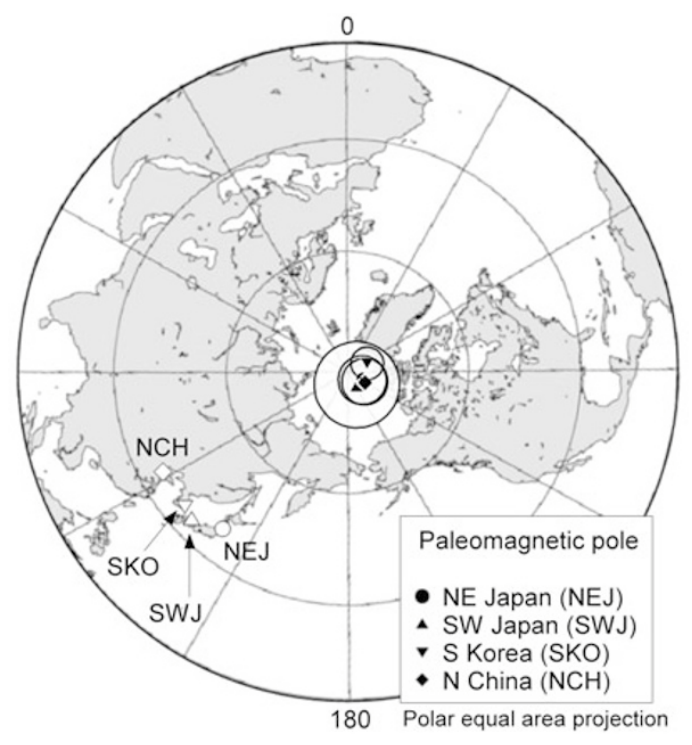

Fig. 7. Middle Miocene paleomagnetic poles for northeast Japan (NEJ: this study), southwestern Japan (SWJ; Otofuji et al., 1991), South Korea (SKO; Lee et al., 1999), and northern China (NCH; Zhao et al., 1994). See Table 2 for data.

sampling areas of northeastern Japan. The mean of six paleomagnetic poles for these areas falls at $85.9^{\circ} \mathrm{N}, 236.6^{\circ} \mathrm{E}$, with $A_{95}=6.2^{\circ}$ (Table 2 ), and we consider this mean to represent the Middle Miocene pole for northeastern Japan. As shown in Fig. 7, this pole is statistically indistinguishable from the North Pole and also from the Middle Miocene paleomagnetic poles for San'in of southwestern Japan (Otofuji et al., 1991), Pohang of South Korea (Lee et al., 1999), and Shandong of northern China (Zhao et al., 1994), which we deem reliable because of moderate $Q(\geq 3)$. This comparison leads us to conclude that northeastern Japan as a whole has suffered no tectonic rotation since the Middle 


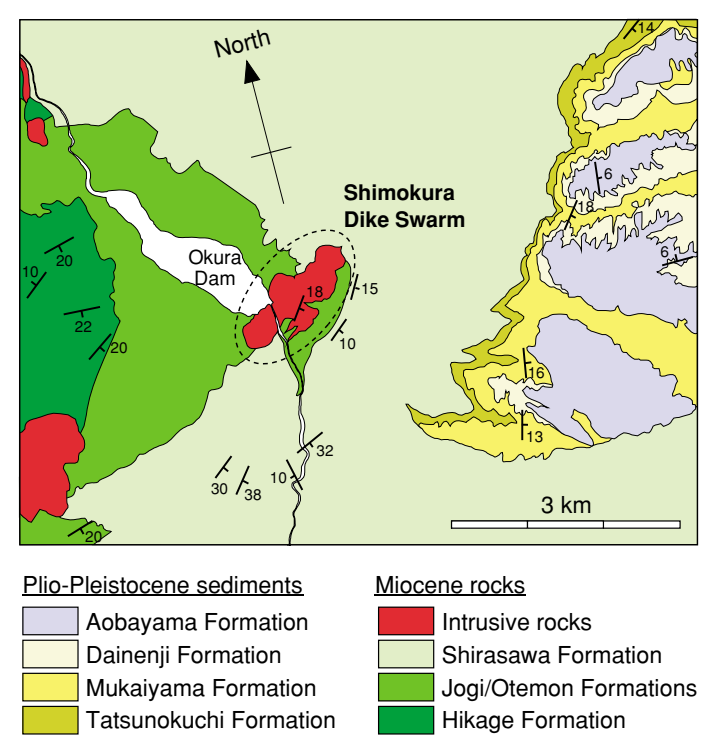

Fig. 8. Simplified geological map around the Shimokura Dike Swarm after Yamaji et al. (1986). Note that eastward- and southeastward-tilted beds are found not only in the Miocene strata intruded by the Shimokura Dike Swarm (approx. $8 \mathrm{Ma}$ ) but also in Plio-Pleistocene sediments distributed to the east (see text).

\section{Miocene.}

The Niigata direction reported by Hirooka et al. (1990) is unusual and suggests a local counterclockwise rotation. The Japan Sea coastal region, on which Niigata is located, is characterized by a severe contractile deformation of the thick sedimentary and volcanic sequences that fill the NNE-trending Early Miocene structural depressions (Yamaji, 1990; Sato, 1994). The sedimentary rock samples that showed the unusual direction were collected from such sedimentary sequences. Geological studies show that folds and reverse faults have been growing up under an east to ESE contractile stress regime since the Pliocene (Sato, 1994; Sato and Kato, 2005). It is possible that local rotation in Niigata is related to the development of these complicated geologic structures. The northwesterly direction of the Middle Miocene Gongenyama Formation on the Japan Sea side of northeastern Japan (Momose et al., 1990) is also supposed to be the result of just such a deformation with a verticalaxis rotation within the back-arc crust.

We have attempted to test the tectonic model of Tsunakawa et al. (1985). They reported a SSE and up paleomagnetic direction $\left(D=162.0^{\circ}, I=-62.1^{\circ}, \alpha_{95}=5.2^{\circ}\right.$, $k=55.0, N=15)$ from the Shimokura Dike Swarm (Fig. 1), and interpreted this to suggest an approximately $20^{\circ}$ counterclockwise rotation. Because the dike swarm was dated at about $8 \mathrm{Ma}$ (Tsunakawa et al., 1983), these researchers hypothesized a counterclockwise rotation of northeastern Japan in the Late Miocene or later. Moreover, there are a few Middle Miocene site mean directions documented from other areas that exhibit a small counterclockwise deflection from the N-S axis (Otofuji et al., 1985b), and Tsunakawa et al. (1985) referred to these directions as supporting data for their model.

Although Tsunakawa et al. (1985) thought that tilt correction is unnecessary for the direction of the Shimokura
Dike Swarm, it is very likely that the dike swarm has been affected by tilting. A geological map around the dike swarm (Yamaji et al., 1986) is shown in Fig. 8, on which we can find that the country rocks, consisting of Late Miocene sediments of the Jogi, Otemon, and Shirasawa Formations, have bedding planes that dip to the east at gentle angles $\left(\leq 20^{\circ}\right)$. Similar structures are also found in Pliocene sediments that crop out to the east of the dike swarm and, accordingly, the Miocene to Pliocene strata form an east-dipping homoclinal succession. The regional tilting undoubtedly occurred during or after the Pliocene, as did the dike swarm. Applying a correction for the gentle tilt to the Shimokura direction, we find a tilt-corrected south and up direction that provides no indication of tectonic rotation.

In the paleomagnetic results reported by Otofuji et al. (1985b), there are a few Middle Miocene site mean directions from two areas of the northern half of northeast Japan (Taiheizan and Zao areas; Fig. 1) showing a counterclockwise declination shift from the N-S axis. Although Otofuji et al. (1985b, 1994) did not regard these directions as an indication of tectonic rotation, Tsunakawa et al. (1985) referred to these as supporting their interpretation. However, the number of the site mean directions is very limited, namely two in each area, and they are obtained from pyroclastic materials. It is probable that they only show a snapshot of the geomagnetic paleosecular variation and, therefore, cannot be the compelling evidence for tectonic rotation.

\section{Conclusions}

The time-averaged, primary paleomagnetic direction of the Ishikoshi Andesite indicates that no rotation has occurred since the Middle Miocene (approx. $14 \mathrm{Ma}$ ). The Middle Miocene paleomagnetic pole for northeast Japan, determined by compiling reliable paleopoles, including our present results, is indistinguishable from those for other regions around the Japan Sea. Northeastern Japan as a whole has, therefore, experienced no rotation since the Middle Miocene. A few northwesterly directions reported from Middle Miocene sequences on the Japan Sea side of northeastern Japan are attributed to deformation with a verticalaxis rotation within the back-arc crust. Our paleomagnetic measurements and geological interpretations question the hypothesis that northeastern Japan rotated counterclockwise in the Late Miocene or later.

Acknowledgments. We thank K. Hayakawa for the help with the magnetic measurements. Constructive reviews by N. Ishikawa, $\mathrm{X}$. Zhao, and T. Yamazaki are greatly appreciated. This study was supported by Grant-in-Aid for Young Scientists (B) of the Ministry of Education, Culture, Sports, Science and Technology (no. 16740286).

\section{References}

Cox, A., Confidence limits for the precision parameter $k$, Geophys. J. R. Astr. Soc., 18, 545-549, 1969.

Fisher, R., Dispersion on a sphere, Proc. R. Soc. London, Ser. A, 217, 295 305, 1953.

Fujiwara, Y., Paleomagnetic studies of the Tertiary rocks in southwestern Hokkaido, Northeast Japan, J. Fac. Sci., Hokkaido Univ., Ser. IV, 23, 159-166, 1992.

Hirooka, K., R. Yamada, M. Yamashita, and A. Takeuchi, Paleomagnetic evidence of the rotation of central Japan and the paleoposition of Japan, 
Palaeogeogr. Palaeoclimatol. Palaeoecol., 77, 345-354, 1990.

Hoshi, H. and T. Matsubara, Early Miocene paleomagnetic results from the Ninohe area, NE Japan: Implications for arc rotation and intra-arc differential rotations, Earth Planets Space, 50, 23-33, 1998.

Hoshi, H. and M. Takahashi, Magnetostratigraphy of the Early to Middle Miocene volcanic sequence in the Motegi area, Northeast Japan, and the time of volcanic activity, J. Geol. Soc. Jpn., 102, 573-590, 1996 (in Japanese with English abstract).

Hoshi, H. and M. Takahashi, Paleomagnetic constraints on the extent of tectonic blocks and the location of their kinematic boundaries: Implications for Miocene intra-arc deformation in Northeast Japan, J. Geol. Soc. Jpn., 103, 523-542, 1997.

Hoshi, H. and M. Takahashi, Miocene counterclockwise rotation of Northeast Japan: a review and new model, Bull. Geol. Surv. Jpn., 50, 3-16, 1999.

Hoshi, H., M. Takahashi, and K. Saito, Paleomagnetic study of Miocene Yoshino Formation, Yamagata Prefecture, Rock Mag. Paleogeophys., 19, 38-42, 1992.

Hoshi, H., K. Sato, and K. Saito, K-Ar dates of some Miocene volcanic rocks from the Yamagata area, Northeast Japan, J. Geol. Soc. Jpn., 104, 722-725, 1998.

Ishii, T., Y. Yanagisawa, S. Yamaguchi, A. Sangawa, and K. Matsuno, Geology of the Matsushima District, 121 pp., Quadrangle Series, 1:50,000, Geol. Surv. Jpn., Tsukuba, 1982 (in Japanese with English abstract).

Ishii, T., Y. Yanagisawa, and S. Yamaguchi, Geology of the Shiogama District, 112 pp., Quadrangle Series, 1:50,000, Geol. Surv. Jpn., Tsukuba, 1983 (in Japanese with English abstract).

Jolivet, L., H. Shibuya, and M. Fournier, Paleomagnetic rotations and the Japan Sea opening, in Active Margins and Marginal Basins of the Western Pacific (Geophys. Monograph 88), edited by B. Taylor, and J. Natland, pp. 355-369, AGU, Washington D.C., 1995.

Kirschvink, J. L., The least squares line and plane and the analysis of palaeomagnetic data, Geophys. J. R. Astr. Soc., 62, 699-718, 1980.

Lee, Y. S., N. Ishikawa, and W. K. Kim, Paleomagnetism of Tertiary rocks on the Korean Peninsula: tectonic implications for the opening of the East Sea (Sea of Japan), Tectonophysics, 304, 131-149, 1999.

Lowrie, W., Identification of ferromagnetic minerals in a rock by coercivity and unblocking temperature properties, Geophys. Res. Lett., 17, 159162, 1990.

Matsuno, K., Geology of the Wakayanagi District, 24 pp., Quadrangle Series, 1:50,000, Geol. Surv. Jpn., Kawasaki, 1967 (in Japanese with English abstract).

McElhinny, M. W. and P. L. McFadden, Paleosecular variation over the past $5 \mathrm{Myr}$ based on a new generalized database, Geophys. J. Int., 131, 240-252, 1997.

Mino, K., A. Yamaji, and N. Ishikawa, The block rotation in the Uetsu area, northern part of Niigata Prefecture, Japan, Earth Planets Space, 53, 805-815, 2001.

Momose, H., M. Torii, and H. Tanaka, Counter-clockwise paleomagnetic direction from the Gongenyama Formation (N9-N10) on the coastal area of Northeast Japan, Rock Mag. Paleogeophys., 17, 47-50, 1990.

Oda, H., M. Torii, and A. Hayashida, Paleomagnetci study and fissiontrack dating in Yanagawa and Takadate area, Northeast Japan, Rock Mag. Paleogeophys., 16, 51-56, 1989.

Okamura, Y., M. Watanabe, R. Morijiri, and M. Satoh, Rifting and basin inversion in the eastern margin of the Japan Sea, Island Arc, 4, 166-181, 1995.

Otofuji, Y., T. Matsuda, and S. Nohda, Opening mode of the Japan Sea inferred from the palaeomagnetism of the Japan Arc, Nature, 317, 603604, 1985a.

Otofuji, Y., T. Matsuda, and S. Nohda, Paleomagnetic evidence for the Miocene counter-clockwise rotation of Northeast Japan: rifting process of the Japan Arc, Earth Planet. Sci. Lett., 75, 265-277, 1985b.

Otofuji, Y., T. Itaya, and T. Matsuda, Rapid rotation of southwest Japan: palaeomagnetism and K-Ar ages of Miocene volcanic rocks of southwest Japan, Geophys. J. Int., 105, 397-405, 1991.

Otofuji, Y., A. Kambara, T. Matsuda, and S. Nohda, Counterclockwise rotation of Northeast Japan: Paleomagnetic evidence for regional extent and timing of rotation, Earth Planet. Sci. Lett., 121, 503-518, 1994.

Sato, H., The relationship between late Cenozoic tectonic events and stress field and basin development in northeast Japan, J. Geophys. Res., 99, 22261-22274, 1994.

Sato, H. and K. Amano, Relationship between tectonics, volcanism, sedimentation and basin development, Late Cenozoic, central part of Northern Honshu, Japan, Sediment. Geol., 74, 323-343, 1991.

Sato, H. and N. Kato, Relationship between geologic structure and the source fault of the 2004 Mid-Niigata Prefecture Earthquake, central Japan, Earth Planet Space, 57, 453-457, 2005.

Shimazu, M., Petrology of the Volcanic Rocks in the Green Tuff Region, 172 pp., Kyoritsu, Tokyo, 1991 (in Japanese).

Takahashi, M., H. Hoshi, and T. Yamamoto, Miocene counterclockwise rotation of the Abukuma Mountains, Northeast Japan, Tectonophysics, 306, 19-31, 1999.

Takeuchi, M. and N. Kaneko, Geology of the Shizugawa District, 93 pp., Quadrangle Series, 1:50,000, Geol. Surv. Jpn., Tsukuba, 1996 (in Japanese with English abstract).

Tamaki, K., K. Suyehiro, J. Allan, J. C. Ingle, Jr., and K. A. Pisciotto, Tectonic synthesis and implications of Japan Sea ODP drilling, in Proc. ODP, Sci.Results, Vol. 127/128, Pt. 2, edited by K. Tamaki, K. Suyehiro, J. Allan, M. McWilliams, et al., pp. 1333-1348, College Station, Texas, 1992.

Tanaka, H., H. Tsunakawa, H. Yamagishi, and G. Kimura, Paleomagnetism of the Shakotan Peninsula, West Hokkaido, Japan, J. Geomag. Geoelectr., 43, 277-294, 1991.

Tosha, T. and Y. Hamano, Paleomagnetism of Tertiary rocks from the Oga Peninsula and the rotation of Northeast Japan, Tectonics, 7, 653-662, 1988.

Toshida, K., K. Uto, and S. Uchiumi, K-Ar ages of volcanic rocks in Shinjo-Sakata area, Tohoku district, Japan, Abstr. 1999 Japan Earth Planet. Sci. Joint Meet., Vc-P001, 1999 (in Japanese).

Tsunakawa, H., A. Takeuchi, and K. Amano, K-Ar ages of dikes in Northeast Japan, Geochem. J., 17, 269-275, 1983.

Tsunakawa, H., K. Heki, and K. Amano, Paleomagnetism of the Shimokura dike swarm in Northeast Japan, J. Geomag. Geoelectr., 37, 979-985, 1985.

Van der Voo, R., The reliability of paleomagnetic data, Tectonophysics, 184, 1-9, 1990.

Van der Voo, R., Paleomagnetism of the Atlantic, Tethys and Iapetus Oceans, 411 pp., Cambridge Univ. Press, Cambridge, 1993.

Van der Werff, W., Backarc deformation along the eastern Japan Sea margin, offshore northern Honshu, J. Asian Earth Sci., 18, 71-95, 2000.

Yamaji, A., Rapid intra-arc rifting in Miocene Northeast Japan, Tectonics, 9, 365-378, 1990

Yamaji, A., K. Amano, K. Otsuki, and T. Ishii, Arc Transect No. 23 (Awashima-Atsumi-Aterazawa-Tendo-Sakunami-Sendai), in Cenozoic Arc Terrane of Northeast Honshu, Japan: Geologic Maps, Geologic Profiles, and Other Basic Data along 30 Arc Transects, edited by N. Kitamura, 36 pp., Hobundo, Sendai, 1986 (in Japanese).

Yamaji, A., H. Momose, and M. Torii, Paleomagnetic evidence for Miocene transtensional deformations at the eastern margin of the Japan Sea, Earth Planets Space, 51, 81-92, 1999.

Yamazaki, T, Paleomagnetism of Miocene sedimentary rocks around Matsushima Bay, Northeast Japan and its implication for the time of the rotation of Northeast Japan, J. Geomag. Geoelectr., 41, 533-548, 1989.

Zhao, X., R. Coe, Y. Zhou, S. Hu, H. Wu, G. Kuang, Z. Dong, and J. Wang, Tertiary paleomagnetism of North and South China and a reappraisal of late Mesozoic paleomagnetic data from Eurasia: Implications for the Cenozoic tectonic history of Asia, Tectonophysics, 235, 181-203, 1994.

Zijderveld, J. D. A., A. C. demagnetization of rocks: Analysis of results, in Method in Palaeomagnetism, edited by D. W. Collinson, K. M. Creer, and S. K. Runcorn, pp. 254-286, Elsevier, Amsterdam, 1967.

H. Hoshi (e-mail: hoshi@auecc.aichi-edu.ac.jp) and Y. Teranishi 